\title{
Microbial Mechanisms of Heat Sensing
}

\author{
Harsha Samtani $^{1} \cdot$ Gopika Unni $^{1} \cdot$ Paramjit Khurana $^{1}$ (i)
}

Received: 18 September 2021 / Accepted: 4 February 2022/Published online: 3 March 2022

(C) Association of Microbiologists of India 2022

\begin{abstract}
Temperature is one of the ubiquitous signals that control both the development as well as virulence of various microbial species. Therefore their survival is dependent upon initiating appropriate response upon temperature fluctuations. In particular, pathogenic microbes exploit host-temperature sensing mechanisms for triggering the expression of virulence genes. Many studies have revealed that the biomolecules within a cell such as DNA, RNA, lipids and proteins help in sensing change in temperature, thereby acting as thermosensors. This review shall provide an insight into the different mechanisms of thermosensing and how they aid pathogenic microbes in host invasion.
\end{abstract}

Keywords Microbes · Pathogen - Temperature ·

Thermosensors · Virulence

\section{Introduction}

Temperature is one of the most important parameters that affects the growth and development of all organisms. Thus, the ability to sense the temperature fluctuations and respond appropriately so as to maintain the internal temperature, has been shared among organisms ranging from bacteria to mammals and has been referred to as thermosensing [1]. It is well known that various microbial species encounter harsh environmental temperatures either due to global warming or when they enter their host species. Therefore, their sustenance is dependent on

Paramjit Khurana

param@genomeindia.org

1 Department of Plant Molecular Biology, University of Delhi South Campus, Benito Juarez Road, New Delhi 110021, India temperature as a cue which can regulate change in growth, development and pathogenesis [2,3].

The expression of heat-shock genes or cold shock genes which mostly code for the chaperone proteins is one of the most well known temperature controlled mechanisms [4]. Activation of the chaperone system helps in preventing protein aggregation and in repairing misfolded protein thereby maintaining the protein homeostasis inside the cell [5]. Temperature changes on the other hand can also modulate the expression of virulence genes in pathogenic viruses and bacteria [2]. DNA replication as well as growth properties of viruses have been reported to be influenced by the temperature in diverse host cell types. Similarly, temperature of $37^{\circ} \mathrm{C}$ serves as a good indicator of host invasion in case of bacteria [3]. Particularly in case of mammalian pathogenic bacteria, elevated temperature indicates successful host invasion leading to activation of virulence genes such as type III secretion system, adhesins and other regulators. Thus, surveying of temperature is critical for not only proper growth of the organism but also for precise coordination of virulence and pathogenesis [3].

At the molecular level, every biomolecule responds to temperature by undergoing conformational change and thus, is employed as a temperature sensor by the cellular machinery. There have been reports of membrane lipids, DNA, RNA and proteins such as chaperone proteins, proteases and kinases being involved in sensing the shift in temperature and regulating the gene expression [6, 7]. Figure 1 depicts the effect of heat stress on different components of the cell which could function as thermosensors. This review provides insight into the different sensing strategies employed by microbes which help in survival under extreme temperatures, particularly heat stress. Moreover, how these strategies help pathogens in host invasion is also discussed and summarized in Table 1. 


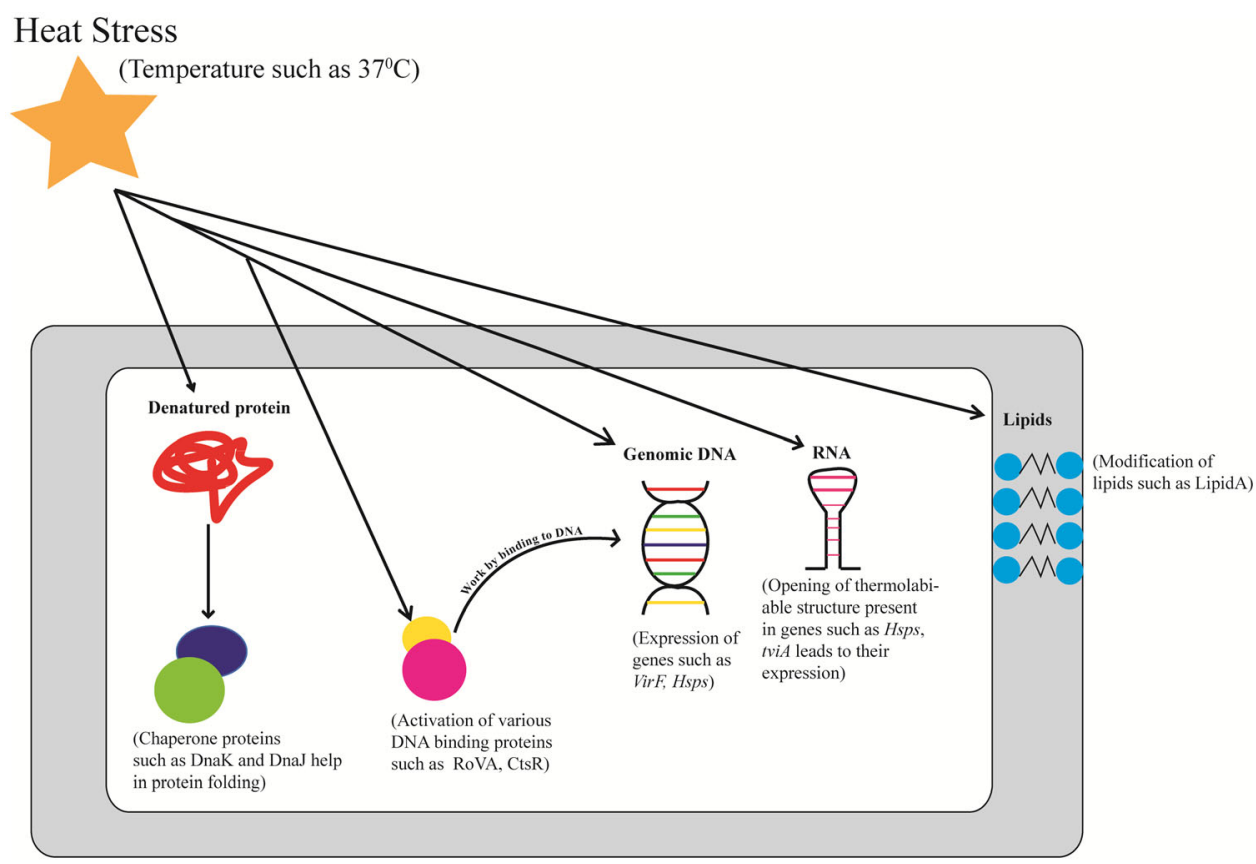

Fig. 1 Schematic diagram depicting the role of various thermosensors present inside the cell upon heat stress. The increase in temperature such as $37^{\circ} \mathrm{C}$ not only acts as heat stress signal for microbes but also serves as a good indicator of host invasion in case of pathogenic microbes. The increase in temperature often leads to the protein unfolding inside the cell which activates the chaperones such as DnaK and DnaJ which assist in protein folding. High temperature also activates other DNA binding proteins such as CtsR and RovA and leads to the transcription of Hsps and invasion proteins required

\section{Membrane Lipids}

\section{Acyl-Lipid Desaturase}

It has been observed that in various microorganisms, the unsaturated fatty acids get altered in response to temperature fluctuation [8]. This is brought about by various desaturase genes (des), which have been identified to function as potential thermosensors. In cyanobacterium Synechocystis, a drop in the temperature (i.e. from 32 to $22{ }^{\circ} \mathrm{C}$ ) causes an increase in the production of the enzyme acyl -lipid desaturases, encoded by $\operatorname{des} A, \operatorname{des} B$ and $\operatorname{des} D$ genes. The expression of these genes have been found to be enhanced by cold stress and thus, they help in increasing the level of cis-unsaturation of the membrane-bound lipid fatty acids so as to regain the membrane's fluidity $[9,10]$. Similar mechanism has been observed in the case of the bacterium Bacillus subtilis when the temperature dropped from 37 to $22{ }^{\circ} \mathrm{C}$. The membrane fluidity was maintained by two proteins i.e. DesK and DesR by regulating the expression of des gene encoding the $\delta 5$-acyl-lipid desaturase $[11,12]$. DesK is a transmembrane Histidine kinase having cytoplasmic kinase/phosphatase domain which can sense the hardness and thickness of cell membrane [9]. At for pathogenesis respectively. Increase in temperature also affects the local DNA structures and thus the binding of regulatory proteins such as H-NS. This causes the expression of genes such as $\operatorname{VirF}$ which is required for virulence. Moreover, stability of RNA thermometers present in the UTR of genes like Hsps and tviA is affected by heat stress thereby leading to translation of Hsps and tviA protein. tviA functions as a transcriptional regulator of virulence factors. Certain microbes synthesize modified lipids such as lipid A upon change in temperature to protect itself from host immune response

low temperatures (below $30{ }^{\circ} \mathrm{C}$ ), the membrane properties promote the Kinase-DesK state which by phosphorylating DesR stimulates the transcription of des gene. On the contrary at high temperatures, the phosphatase-DesK dominates leading to dephosphorylated DesR which results in the termination of des gene transcription [12].

\section{LpxD1 and LpxD2}

Lipid A is the biologically active component of the Lipopolysaccharide that can trigger an immune response in the host cells. Thus, certain organisms synthesize modified forms of lipid A in response to change in temperature, so as to alter the outer membrane's integrity and protect itself from host's immune response [13]. For example, the bacteria Fransciella, while entering a mammalian host remodels its membrane by altering lipid A using enzyme acyltransferase LpxD1/2 and these have been reported to be differentially upregulated at mammalian temperature $\left(37^{\circ} \mathrm{C}\right)$ and at environmental temperature $\left(21^{\circ} \mathrm{C}\right)$ respectively [14, 15]. Moreover, the modification of lipid A by Fransciella also helps it to increase the overall charge on its surface and thus repel cationic antimicrobials produced by the host [16]. Similarly studies with Yersinia pestis 
Table 1 Table depicting the role of various thermosensors (with examples of different microbes)

\begin{tabular}{|c|c|c|c|c|}
\hline Thermosensor & Organisms & Mode of Action & Advantage to Microbe/Pathogenesis & References \\
\hline \multicolumn{5}{|l|}{ Membrane lipids } \\
\hline $\begin{array}{l}\text { Acyl-lipid } \\
\text { desaturase }\end{array}$ & $\begin{array}{l}\text { Synechocystis, } \\
\text { Bacillus subtilis }\end{array}$ & $\begin{array}{l}\text { The Decrease in temperature (below } \\
30{ }^{\circ} \mathrm{C} \text { ) leads to activation of Des } \\
\text { genes }\end{array}$ & $\begin{array}{l}\text { Activation of Des genes help in } \\
\text { maintaining the membrane fluidity }\end{array}$ & {$[10,12]$} \\
\hline $\begin{array}{l}\text { Acyltransferase } \\
\text { LpxD1 \& } \\
\text { LpxD2 }\end{array}$ & $\begin{array}{l}\text { Fransiella, } \\
\text { Yersinia pestis }\end{array}$ & $\begin{array}{l}\text { On encountering mammalian host } \\
\text { temperature }\left(37^{\circ} \mathrm{C}\right) \text {, these organisms } \\
\text { modify lipid A with the help of } \\
\text { acyltransferases }\end{array}$ & $\begin{array}{l}\text { Modified lipid A helps in repelling } \\
\text { antimicrobial peptides, reduced } \\
\text { activation of macrophages leading to } \\
\text { evasion of host defence }\end{array}$ & {$[16,17]$} \\
\hline \multicolumn{5}{|l|}{ DNA } \\
\hline $\begin{array}{l}\text { Positive } \\
\text { Supercoiling }\end{array}$ & Salmonella & $\begin{array}{l}\text { Upon heat exposure, the positive } \\
\text { supercoiling of DNA leads to SPI-1 } \\
\text { expression }\end{array}$ & $\begin{array}{l}\text { The SPI-1 expression initiates the } \\
\text { intestinal invasion }\end{array}$ & [19] \\
\hline $\begin{array}{l}\text { Promoter } \\
\text { curvature }\end{array}$ & Clostridium perfringens & $\begin{array}{l}\text { The phospholipase } \mathrm{C}(\mathrm{plc}) \text { gene was } \\
\text { found to possess three poly (A) tracts } \\
\text { forming bent DNA upstream of the } \\
\text { promoter. This bent DNA facilitated } \\
\text { transcription of the plc gene in a low } \\
\text { temperature }\left(25^{\circ} \mathrm{C}\right) \text { dependent } \\
\text { manner }\end{array}$ & $\begin{array}{l}\text { Efficient expression of the plc gene at } \\
\text { low temperature facilitates in } \\
\text { fulfilling commensal and saprophytic } \\
\text { lifestyle }\end{array}$ & {$[20]$} \\
\hline $\begin{array}{l}\text { Nucleoid } \\
\text { associated } \\
\text { proteins }\end{array}$ & $\begin{array}{l}\text { Salmonella enterica, } \\
\text { Shigella flexneri }\end{array}$ & $\begin{array}{l}\text { At normal temperatures, H-NS } \\
\text { represses the expression of the genes } \\
\text { required for invasion such as } S P I-2 \\
\text { and VirF. Upon host invasion, the rise } \\
\text { in temperature }\left(37^{\circ} \mathrm{C}\right) \text { affects the } \\
\text { DNA binding ability of H-NS }\end{array}$ & $\begin{array}{l}\text { The decreased affinity of } \mathrm{H}-\mathrm{NS} \\
\text { proteins for their target sites } \\
\text { facilitates the transcription of host } \\
\text { invasion genes }\end{array}$ & {$[18,21]$} \\
\hline \multicolumn{5}{|l|}{ RNA } \\
\hline ROSE Elements & Pseudomonas aeruginosa & $\begin{array}{l}\text { ROSE element located in the UTR of } \\
\text { rhlA and lasI gene regulate their } \\
\text { translation. At } 30^{\circ} \mathrm{C} \text {, the hairpin loop } \\
\text { structure prevent ribosome binding to } \\
\text { SD sites. However, heat induced } \\
\left(37^{\circ} \mathrm{C}\right) \text { structural changes expose the } \\
\text { SD sites thereby allowing translation }\end{array}$ & $\begin{array}{l}\text { Higher temperatures help in the } \\
\text { production of Quorum-sensing } \\
\text { dependent virulence factors }\end{array}$ & [29] \\
\hline fourU Elements & $\begin{array}{l}\text { Salmonella Typhimurium, } \\
\text { Yersinia ss }\end{array}$ & $\begin{array}{l}\text { Hairpin structure control the translation } \\
\text { of virulence related genes such as } \\
\text { htrA, LcrF }\end{array}$ & $\begin{array}{l}\text { Upon host invasion the increase in } \\
\text { temperature leads to disruption of the } \\
\text { hairpin structure thereby promoting } \\
\text { the translation of these virulent genes }\end{array}$ & {$[26,31]$} \\
\hline $\begin{array}{c}\text { Cyanobacterial } \\
\text { thermometer }\end{array}$ & Synechocystis & $\begin{array}{l}\text { Single stem loop structure controls the } \\
\text { expression of heat shock genes }\end{array}$ & $\begin{array}{l}\text { Under heat stress conditions, opening } \\
\text { of stem loop leads to expression of } \\
\text { hsps which aid in protein folding }\end{array}$ & {$[32]$} \\
\hline $\begin{array}{l}\text { Alternate sigma } \\
\text { factor }\end{array}$ & $\begin{array}{l}\text { E.coli, } \\
\text { Borrelia burgdorferi }\end{array}$ & $\begin{array}{l}\text { Secondary structure of mRNA regulate } \\
\text { the translation of heat shock genes in } \\
\text { E.coli and virulence related genes } \\
(\text { OspC and } O s p A) \text { in Borrelia } \\
\text { burgdorferi under normal conditions. } \\
\text { High temperature destabilizes the } \\
\text { structure thereby allowing translation } \\
\text { to proceed }\end{array}$ & $\begin{array}{l}\text { Heat induced translation of these genes } \\
\text { provides protection against rise in } \\
\text { temperature and helps in transcription } \\
\text { of virulent genes }\end{array}$ & {$[33,34]$} \\
\hline $\begin{array}{l}\text { Csp } \\
\text { thermometer }\end{array}$ & E coli & $\begin{array}{l}\text { The RNAT in the UTR of CspA genes } \\
\text { adopts a stable conformation at } 10^{\circ} \mathrm{C} \\
\text { with the SD sequence being exposed. } \\
\text { This leads to the translation of CspA } \\
\text { protein }\end{array}$ & $\begin{array}{l}\text { CspA protein helps in survival under } \\
\text { cold shock conditions }\end{array}$ & {$[4]$} \\
\hline $\begin{array}{l}\text { cIII } \\
\text { thermometer }\end{array}$ & Bacteriophage $\lambda$ & $\begin{array}{l}\text { The cIII gene product is controlled by } \\
\text { RNAT which exists as two mutually } \\
\text { exclusive structures. These structures } \\
\text { change in a temperature dependent } \\
\text { manner }\end{array}$ & $\begin{array}{l}\text { Based on temperature, the phage } \\
\text { decides to enter either lytic (virulent) } \\
\text { or lysogeny (avirulent) phase }\end{array}$ & {$[28]$} \\
\hline
\end{tabular}


Table 1 continued

\begin{tabular}{|c|c|c|c|c|}
\hline Thermosensor & Organisms & Mode of Action & Advantage to Microbe/Pathogenesis & References \\
\hline \multirow[t]{7}{*}{ Other RNAT } & $\begin{array}{l}\text { Yersinia } \\
\quad \text { pseudotuberculosis }\end{array}$ & $\begin{array}{l}\text { The thermolabile stem loop structure } \\
\text { regulates the expression of secreted } \\
\text { toxin }\left(\mathrm{CNF}_{\mathrm{Y}}\right) \text { by occluding the RBS } \\
\text { at } 25^{\circ} \mathrm{C} \text { and liberating it at } 37^{\circ} \mathrm{C}\end{array}$ & $\begin{array}{l}\text { The secretion of toxin upon elevated } \\
\text { temperature helps in host immune } \\
\text { evasion }\end{array}$ & {$[37]$} \\
\hline & Neisseria meningitidis & $\begin{array}{l}\text { The RNAT present in the UTR of CssA } \\
\text { gene allows its translation upon high } \\
\text { temperature stress }\end{array}$ & $\begin{array}{l}\text { The expression of this immune evasion } \\
\text { factor helps in invading the host }\end{array}$ & {$[38]$} \\
\hline & Listeria monocytogenes & $\begin{array}{l}\text { Thermolabile RNAT harboring internal } \\
\text { loops around AUG and RBS regulates } \\
\text { the expression of } \operatorname{prfA} \text {, which is a } \\
\text { master regulator of virulence }\end{array}$ & $\begin{array}{l}\text { Upon encountering } 37{ }^{\circ} \mathrm{C} \text {, prfA protein } \\
\text { is translated which is responsible for } \\
\text { further expression of nine key } \\
\text { virulence genes. This helps in host } \\
\text { invasion }\end{array}$ & [39] \\
\hline & Salmonella Typhi & $\begin{array}{l}\text { A stem loop structure regulates the } \\
\text { expression of } t v i A \text { gene, which is a } \\
\text { transcriptional regulator of virulence } \\
\text { factors. Melting of RNAT upon } \\
\text { elevated temperature facilitates the } \\
\text { translation of } t v i A\end{array}$ & $\begin{array}{l}\text { On host invasion, the rise in } \\
\text { temperature trigger tviA translation. } \\
\text { This leads to Vi capsule formation } \\
\text { and suppression of flagellin and type } \\
\text { III secretion system which is } \\
\text { necessary to evade immune response }\end{array}$ & {$[40]$} \\
\hline & Streptococcus pneumoniae & $\begin{array}{l}\text { Temperature sensitive RNAT structures } \\
\text { regulates the production of } \\
\text { polysaccharide capsule }\end{array}$ & $\begin{array}{l}\text { Inflammation triggered rise in } \\
\text { temperature in host cells leads to } \\
\text { production of capsule and factor } \mathrm{H}\end{array}$ & {$[41]$} \\
\hline & Haemophilus influenza & $\begin{array}{l}\text { Production of factor } \mathrm{H} \text { binding protein } \\
\text { is regulated by temperature sensitive } \\
\text { RNAT }\end{array}$ & $\begin{array}{l}\text { binding protein. These aid in evading } \\
\text { the immune response }\end{array}$ & \\
\hline & Staphylococcus aureus & $\begin{array}{l}\text { RNAT having two hairpin structures } \\
\text { controlled the expression of cidA } \\
\text { gene. Low temperatures such as } \\
30^{\circ} \mathrm{C} \text { facilitates translation of cidA }\end{array}$ & $\begin{array}{l}\text { cidA protein helps in biofilm } \\
\text { production and pathogen survival }\end{array}$ & {$[42]$} \\
\hline \multicolumn{5}{|c|}{ Protein thermosenosrs } \\
\hline \multirow[t]{2}{*}{$\begin{array}{l}\text { Transcription } \\
\text { regulators }\end{array}$} & $\begin{array}{l}\text { Salmonella, } \\
\text { Yersinia }\end{array}$ & $\begin{array}{l}\text { TlpA protein in Salmonella and RoVA } \\
\text { in Yersinia binds to DNA at low } \\
\text { temperatures }\left(20^{\circ} \mathrm{C}-25^{\circ} \mathrm{C}\right) \text { and } \\
\text { represses the transcription of virulent } \\
\text { genes. However, at } 37^{\circ} \mathrm{C} \text { the } \\
\text { conformational change in the protein } \\
\text { reduces their affinity for DNA } \\
\text { binding, thereby allowing } \\
\text { transcription to occur }\end{array}$ & $\begin{array}{l}\text { The expression of virulent genes upon } \\
\text { host invasion helps in the invasion of } \\
\text { the immune response }\end{array}$ & {$[44,45]$} \\
\hline & $\begin{array}{l}\text { Bacillus subtilis, } \\
\text { Staphylococcus } \\
\text { saprophyticus, } \\
\text { Chlamydia trachomatis }\end{array}$ & $\begin{array}{l}\text { CtsR and HrcA proteins bind the } \\
\text { promoter of various Hsps and repress } \\
\text { the transcription of various Hsps. } \\
\text { Heat stress such as } 50{ }^{\circ} \mathrm{C} \text { represses } \\
\text { the activity of these proteins thereby } \\
\text { allowing transcription of these genes }\end{array}$ & $\begin{array}{l}\text { Expression of Hsps helps in providing } \\
\text { protection against heat stress }\end{array}$ & {$[47-49]$} \\
\hline $\begin{array}{l}\text { Methyl- } \\
\text { accepting } \\
\text { chemotaxis } \\
\text { proteins }\end{array}$ & E coli & $\begin{array}{l}\text { Tsr and Tar receptors sense the change } \\
\text { in temperature through the presence } \\
\text { of Serine and Aspartate }\end{array}$ & $\begin{array}{l}\text { These receptors provide survival } \\
\text { advantage under diverse } \\
\text { environmental conditions }\end{array}$ & {$[53]$} \\
\hline $\begin{array}{l}\text { Chaperones and } \\
\text { proteases }\end{array}$ & E coli & $\begin{array}{l}\text { Chaperones bind unfolded polypeptides } \\
\text { and maintain them in a folding- } \\
\text { competent state during heat stress } \\
\text { Proteases get activated during heat } \\
\text { shock and cleaves other proteins so as } \\
\text { to release specific heat shock protein } \\
\text { and thus aid in protein folding }\end{array}$ & $\begin{array}{l}\text { These proteins aid in maintaining } \\
\text { homeostasis under heat stress }\end{array}$ & {$[54,60]$} \\
\hline
\end{tabular}


Table 1 continued

\begin{tabular}{|c|c|c|c|c|}
\hline Thermosensor & Organisms & Mode of Action & Advantage to Microbe/Pathogenesis & References \\
\hline \multicolumn{5}{|l|}{ Miscellaneous } \\
\hline \multirow[t]{3}{*}{ Kinases } & $\begin{array}{l}\text { Bacillus subtilis, } \\
\text { Synechocystis sp, }\end{array}$ & $\begin{array}{l}\text { Histidine kinases such as DesK and } \\
\text { Hik33 perceive the cold induced } \\
\text { changes in the membrane such as } \\
\text { thickness and fluidity. Upon } \\
\text { activation, they further regulate the } \\
\text { expression of genes affecting } \\
\text { membrane fluidity }\end{array}$ & $\begin{array}{l}\text { They help in the maintenance of } \\
\text { membrane fluidity under cold stress }\end{array}$ & {$[63,65]$} \\
\hline & Agrobacterium tumefaciens & $\begin{array}{l}\text { Temperature below } 32{ }^{\circ} \mathrm{C} \text { activates } \\
\text { VirA which then activates other vir } \\
\text { genes }\end{array}$ & $\begin{array}{l}\text { Activation of vir genes help in transfer } \\
\text { of T-DNA from Agrobacterium to the } \\
\text { plants }\end{array}$ & {$[51]$} \\
\hline & $\begin{array}{l}\text { Histoplasma capsulatum, } \\
\text { Blastomyces dermatitidis }\end{array}$ & $\begin{array}{l}\text { Activation of Histidine kinase Drk1 } \\
\text { occurs in response to temperature, } \\
\text { which leads to a signaling cascade }\end{array}$ & $\begin{array}{l}\text { It helps in adapting the fungi under } \\
\text { stress conditions in mammalian host }\end{array}$ & {$[2]$} \\
\hline $\begin{array}{l}\text { Type VI } \\
\text { secretion } \\
\text { system }\end{array}$ & Vibrio cholerae & $\begin{array}{l}\text { Functioning of the Type VI secretion } \\
\text { system reduces at higher temperatures } \\
\text { i.e. } 37^{\circ} \mathrm{C}\end{array}$ & $\begin{array}{l}\text { It facilitates various aspects like } \\
\text { virulence, inter-species competition } \\
\text { and natural transformation }\end{array}$ & {$[66]$} \\
\hline
\end{tabular}

showed that at a temperature range of $21-28^{\circ} \mathrm{C}$, it produced hexacylated lipid A structure whereas at mammalian host temperature $\left(37^{\circ} \mathrm{C}\right)$ tetraacylated lipid A structures were produced. This modification reduced the activation of macrophages thereby enabling successful infection by escaping the host defence [17].

\section{DNA}

\section{Supercoiling}

DNA topology influences transcription and thus, any change in the supercoiling pattern can result in a rapid and efficient alteration of the gene expression during stress conditions [18]. DNA topology has been shown to play an important role in pathogenicity of organisms such as Salmonella. Upon encountering exposure to heat, DNA undergoes positive supercoiling thereby triggering SPI-1 gene expression and subsequent initiation of intestinal invasion [19].

\section{Promoter Curvature}

Temperature sensing can also occur by local DNA structures that affect the transcription of neighbouring genes. Particularly, intrinsically curved DNA regions characterized by AT-rich tracts are often located on the upstream of the promoter region and affect the binding ability of RNA polymerase due to temperature changes [18]. Bacterium Clostridium perfringens provides the best example as the promoter of the plc gene, which encodes for the enzyme phospholipase $\mathrm{C}$. The promoter was found to have three A tracts which functioned as an RNA polymerase binding site $[20,21]$. Low temperature increased the bending of these A tracts and enhanced the binding affinity for the polymerase, thereby facilitating transcription [20].

\section{Nucleoid-Associated Proteins}

Temperature-dependent local DNA structures can indirectly affect the gene transcription by influencing the interaction of DNA binding proteins that have a regulatory role. These include nucleoid associated proteins such as $\mathrm{H}-\mathrm{NS}$, which preferentially binds to AT-rich sequences and functions in a temperature-responsive manner [18]. At temperatures above $37{ }^{\circ} \mathrm{C}$, these proteins are unable to form higher-order oligomers and bind the DNA, whereas at lower temperature (upto $30{ }^{\circ} \mathrm{C}$ ), the ratio of $\mathrm{H}$-NS proteins to DNA increases three-to-four-fold [22]. This property of $\mathrm{H}-\mathrm{NS}$ proteins plays a key role in virulence gene expression in many human pathogens.

It has been reported that in Salmonella enterica, the genomic island (SPI-2) that codes for Type III secretion system, was thermally regulated by the H-NS proteins. H-NS repressed the expression of SPI-2 at non-permissive temperature $\left(\leq 30{ }^{\circ} \mathrm{C}\right)$ by binding to the DNA. However, at higher temperature, the DNA binding capability of H-NS was affected, leading to the transcription of this gene and promoting intracellular transcription [18, 23] (Fig. 2a). Similarly in the case of pathogenic bacteria Shigella flexneri, the virF gene required for invasion was kept repressed at non-permissive temperature (below $32^{\circ} \mathrm{C}$ ) by $\mathrm{H}-\mathrm{NS}$ proteins [18, 24]. Moreover, the two H-NS binding sites in the virF promoter were reported to be separated by an 
Fig. 2 Functioning of various thermosensors inside the cell. a DNA thermosensor. H-NS proteins affects the DNA bending and transcription process, as increase in temperature disables the formation of higher-order oligomers, thereby leading to opening of bent DNA and allowing RNA Polymerase to proceed transcription. b RNA thermosensor. The formation of RNA thermometer at low temperatures leads to the pairing of the Shine Dalgarno sequence and the AUG start codon. The rise in temperatures causes melting of the structure which permits the binding of the ribosome (30S and 50S) and allows translation. c Protein thermosensor. The repressor proteins forms dimmer and bind to the DNA at normal temperatures, thereby blocking its transcription. Upon heat shock, these proteins lose their conformation and dissociate from the DNA, allowing transcription to occur (a)

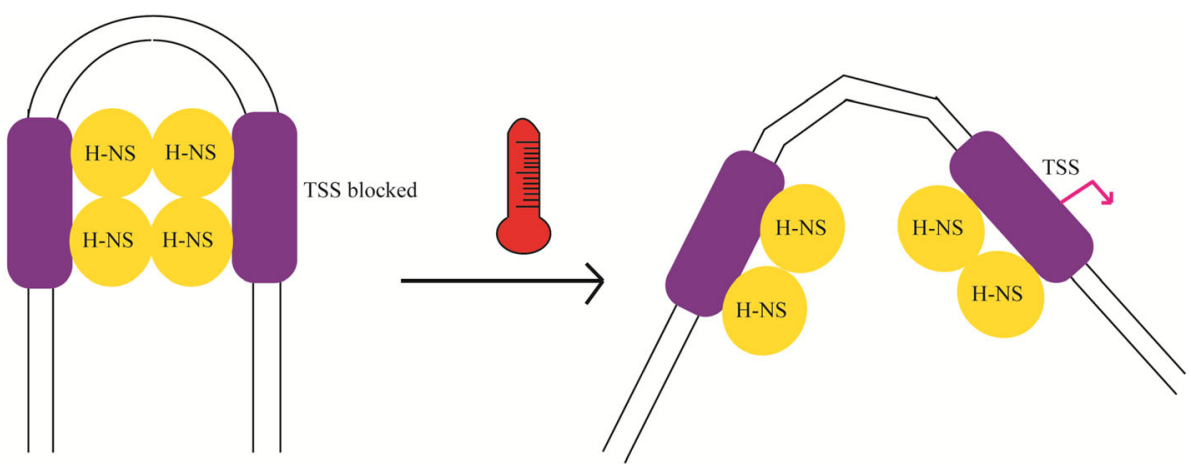

(b)
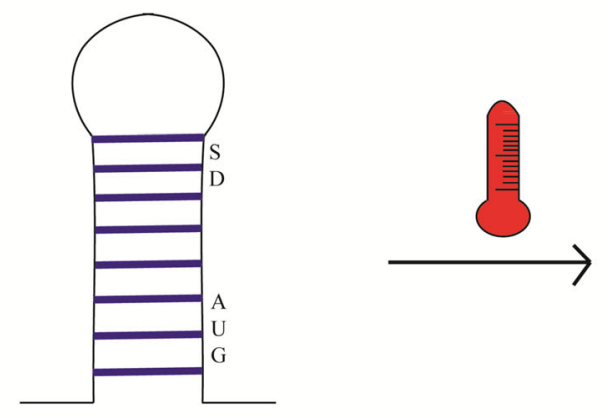

(c)

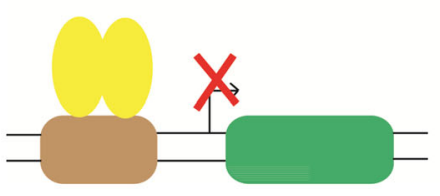

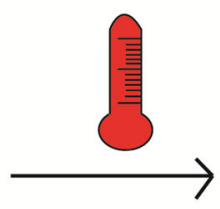

intrinsically bent region and thus higher temperatures by affecting the binding of $\mathrm{H}-\mathrm{NS}$ to the target sites allowed the transcription of virF genes [21]. Expression of hemolysin gene in E.coli was also demonstrated to be regulated by an interplay of DNA bending and H-NS binding proteins [21]. Two H-NS binding sites in hemolysin operon were found to be separated by intrinsic DNA curvature. Therefore the increased flexibility of DNA and higher affinity of H-NS protein at lower temperatures caused the formation of a nucleoprotein complex which repressed the transcription. However, high growth temperature facilitated expression of hemolysin [25]. Thus, H-NS plays an important role in thermoregulation of virulence genes.

\section{RNA}

RNA thermosensors are basically RNA sequences present in the 5' UTR of the genes with the ability to form secondary structures that could mask the ribosome binding site (RBS). Heat stress destabilises these structures thereby liberating the RBS and allowing the translation of the gene [26] (Fig. 2b). RNA thermosensors provide faster gene regulation in a cost-efficient manner in comparison to protein based gene regulation. Several temperature sensing RNA sequences known as RNA thermometers (RNAT's) have been identified in various microorganisms [21].

\section{ROSE Elements}

ROSE elements (repression of heat shock gene expression), is the most common class of RNAT and were first discovered in Bradyrhizobium japonicum [27]. ROSE elements located in the 5'-UTR of the small heat shock genes, form a complex structure comprising 2-4 stem loops consisting of the Shine-Dalgarno sequence (SD sequence) and sometimes even the AUG start codon [21]. Studies have shown that the $\mathrm{SD}$ region remained sequestered at $30{ }^{\circ} \mathrm{C}$, but with the gradual rise in temperature such as $37{ }^{\circ} \mathrm{C}$, partial melting of the hairpin occured. Further, temperature of $42{ }^{\circ} \mathrm{C}$ caused full liberation of the SD and AUG start codon due to the complete melting of the hairpin structure [26]. Due to its gradual response to temperature alterations in vivo and in vitro, the ROSE element acts like a typical zipper and has been observed in various Rhizobia 
[28]. In opportunistic pathogens such as Pseudomonas aeruginosa, studies have identified ROSE regulating the expression of rhlR and lasI genes, which are required for the virulence [29].

\section{fourU Elements}

These are another class of RNAT, based on a stretch of four uridines that pairs with AGGA in the SD sequence [28]. fourU element was first identified to be present upstream of the small heat shock gene aggregation suppressing A (agsA) in Salmonella enterica and was found to control its translation initiation [30]. Secondary-structure prediction and experimental RNA probing showed that this element consisted of two hairpins wherein the second hairpin was temperature controlled and it sequestered the SD region through the fourU motif. High temperatures such as $40-45^{\circ} \mathrm{C}$, caused melting of hairpin II thereby allowing the binding of the ribosomes to the SD sequence $[18,30]$. Such fourU elements consisting of a single hairpin also controlled the translation of htrA gene coding for periplasmic Serine protease in Salmonella Typhimurium [26]. Similar control of translation have been reported in the case of virulence factor LcrF in Yersinia ss, iron-acquisition gene in Shigella dysenteriae and transcriptional activator protein ToxT in Vibrio cholerae [18, 31].

\section{Cyanobacterial Thermometer}

This is the simplest natural RNAT, being first identified in the upstream region of the heat shock protein 17 gene (hsp17) in Synechocystis which is only 46 nucleotide long [32]. It was found to form a single stem-loop structure which could open and close in a reversible manner. Thus, with the help of RNAT, cyanobacteria control the expression of small heat shock genes [32].

\section{Alternate Sigma Factor}

In E.coli heat shock response is regulated by alternative sigma factor $\sigma^{32}$, which is encoded by the $r p o H$ gene. It was found to function as a thermosensor and was regulated at the translational level by the two distinct regions which resided within the coding region [18]. The open reading frame of $r p o H$ formed a highly structured mRNA containing several three way junctions at lower temperature, thereby, preventing the entry of ribosome to the SD sequence [33]. Melting of this RNA structure at higher temperature $\left(\geq 37^{\circ} \mathrm{C}\right)$ led to the SD sequence being accessible for translation of the sigma factor which induced the heat shock response [6].

Another alternative sigma factor $\operatorname{RpoS}\left(\sigma^{\mathrm{S}}\right.$ or $\left.\sigma^{38}\right)$ was found to regulate the virulence-associated major outer surface proteins OspC and OspA in the spirochete Borrelia burgdorferi [6, 34]. Moreover, a small non-coding RNA, DsrA $_{\mathrm{Bb}}$, regulated temperature-induced increase in RpoS as with the upshift in temperature, its secondary structure melted, and it interacted with the anti-SD region of the RpoS mRNA. This released the sequestered SD sequence leading to translation under virulence conditions i.e. $37{ }^{\circ} \mathrm{C}$ $[4,35]$.

\section{Csp Thermometer}

In $E$ coli, cold shock leads to the expression of Cold shock protein A (CspA), an RNA chaperone that binds singlestranded RNAs to prevent the formation of any secondary structures during stress [36]. The expression of CspA was found to be controlled by the help of the RNAT present in the 5' UTR of the gene, thereby attributing thermosensing properties [4]. Lower temperatures (such as $10^{\circ} \mathrm{C}$ ) favoured mutually exclusive alternative structures causing the rearrangements of the CspA RNAT resulting in the 'cold shock structure' being translated efficiently. However, at $37{ }^{\circ} \mathrm{C}$, the translation initiation elements remained buried within a double-stranded structure that hindered the translation efficiency [4].

\section{cIII Thermosensor}

The fate of Bacteriophage $\lambda$ to enter the lytic phase or lysogenic phase depends on the cIII gene product, which was found to be temperature responsive and controlled by RNAT [28]. The RNAT existed in two mutually exclusive structures i.e. A (translation OFF) and B (translation $\mathrm{ON}$ ) which functioned in switch-like fashion. The structure $\mathrm{B}$ dominated at temperature below $37{ }^{\circ} \mathrm{C}$ ensuring the interaction between the anti-SD site and an anti-anti-SD site, thereby making the SD site accessible for translation. The translation of cIII mRNA led to the lysogenic pathway [28]. At $45^{\circ} \mathrm{C}$, the structural rearrangement causes the domination of structure $\mathrm{A}$ and thus the SD site gets sequestered due to interaction with the anti-SD site. This prevents the translation of cIII, thereby driving the phage into the lytic pathway [28].

\section{Some Examples of Other RNAT Conferring Virulence}

Recent report highlighted that RNAT played a pivotal role in production of secreted toxin cytotoxic necrotizing factor $\left(\mathrm{CNF}_{\mathrm{Y}}\right)$ in bacterial pathogen Yersinia pseudotuberculosis which helps in evading the host immune system [37]. A thermo labiable stem loop structure was identified in the 5'UTR of $\mathrm{CNF}_{\mathrm{Y}}$ gene in which the RBS was occluded at $25{ }^{\circ} \mathrm{C}$ but was liberated at $37{ }^{\circ} \mathrm{C}$. Similarly in case of 
Neisseria meningitidis, RNAT controlled the expression of CssA, which is a bacterial immune evasion factor. The stability of the RNAT present in the 5'UTR region was found to respond to a temperature of $37{ }^{\circ} \mathrm{C}$ which caused the opening up of the structure and subsequent access to RBS [38]. In Listeria monocytogenes, RNAT regulated the expression of key transcription factor prfA which functions as a master regulator of virulence [26]. Studies demonstrated that prfA RNAT is highly responsive to a narrow temperature range and thus transition from 30 to $37^{\circ} \mathrm{C}$ leads to unfolding of the two internal loops surrounding the RBS and AUG regions. Moreover, distal regions have also been identified to stabilize RNA structure and regulate its translation [39]. Similarly, RNT located in the 5'UTR of transcriptional regulator tviA of Salmonella Typhi have been shown to regulate virulence and innate immune evasion in response to host temperature. [40]. tviA functions as a transcriptional regulator of virulence factors such as $\mathrm{Vi}$ capsule, flagellin and type III secretion system. Thus upon host invasion, the RNAT melts open thereby enabling ribosome access to the $\mathrm{SD}$ region and translation of tviA transcript. tviA protein inturn promotes more Vi capsule formation and suppression of flagellin and type III secretion system which is necessary to evade recognition by and activation of innate immune response [40]. Moreover, recent studies on meningitis-causing bacteria such as Streptococcus pneumoniae and Haemophilus influenza have demonstrated that the production of polysaccharide capsule and factor $\mathrm{H}$ binding proteins were regulated by temperature responsive RNAT located upstream of the genes. Thus upon sensing the increase in temperature, RNAT provide better protection and immune evasion by expression of these genes [41]. Interestingly, an unconventional RNA thermosensor has also been detected to regulate Staphylococcus aureus cidA gene which is required for biofilm formation and survival of the pathogen. Unlike other bacterial RNAT, this thermosensor was found to facilitate translation at low temperature (i.e. $30{ }^{\circ} \mathrm{C}$ ) and is speculated to function by a different molecular mechanisms [42]. For a detailed role of RNA thermometers in bacterial pathogenesis readers may refer to [43].

\section{Proteins}

\section{Transcription Regulators}

Some of the bacterial heat shock and virulence genes have been reported to be controlled by the temperature-responsive repressor proteins. In Salmonella, TlpA was found to be a temperature responsive autoregulatory repressor protein and was observed to be functional at low but not at high temperatures such as those encountered upon host infection [44]. Studies have revealed that at lower temperatures $\left(<37^{\circ} \mathrm{C}\right)$, it dimmerises and binds the DNA thereby blocking transcription whereas at higher temperature the dimmer dissociates leading to gene expression (Fig. 2c). Apart from repressing its own transcription, it also represses the expression of other virulence associated genes [44]. Similarly in pathogens such as Yersinia, transcriptional regulator RovA controls the expression of itself and of the invasin protein required for pathogenesis [45]. At temperature $20-25{ }^{\circ} \mathrm{C}$, RovA was found to be active and bound the target sites (rovA promoter and invA promoter) with high affinity, thereby preventing their transcription. An upshift to $37^{\circ} \mathrm{C}$ caused the conformational change in RovA which reduced its DNA binding capacity and thus allowed the expression of target genes.

Hsps in various gram positive bacteria are jointly regulated by $\mathrm{CtsR}$ and $\mathrm{HrcA}$ repressor proteins which binds to CtsR box and CIRCE (Controlling inverted repeat of chaperone expression) respectively [46]. In Bacillus subtilis, DNA binding capability of CtsR was found to be functional only at $37{ }^{\circ} \mathrm{C}$ and thus, suppressed the transcription under normal conditions. Whereas at heat-shock temperatures $\left(50{ }^{\circ} \mathrm{C}\right)$, CtsR had reduced activity, thereby making the promoter accessible for transcription of target genes [47]. In case of Streptococci, both CtsR and HrcA control the overlapping regulons harboring most of the Hsps [48]. Report by Rossi et al. [46] also indicated that in case of Staphylococcus saprophyticus, both the repressor proteins control the expression of Hsps. Similarly, studies on Chlamydia trachomatis during intracellular infection confirmed the regulation of heat shock genes by HrcA within the infected cell [49]. In Campylobacter jejuni, the DNA binding activity of HrcA is regulated by HspR and GroE proteins under heat shock conditions, which enhances its function as an intrinsic protein thermometer [50].

\section{Methyl-Accepting Chemotaxis Proteins (MCPs)}

It has been well known that upon small changes in temperature, Escherichia coli responds by altering its swimming behaviour [51]. Tsr and Tar have been documented to be two receptors that sense Serine and Aspartate respectively and are involved in this chemotaxis mechanism [52]. The roles of these receptors have also been observed in sensing temperature, referred to as thermotaxis. Studies have shown that in the absence of both Serine and Aspartate, the receptors lead to the movement towards hotter regions [53]. However, in the presence of Aspartate, Tar promotes the heat seeking response whereas Tsr promotes cold-seeking response thereby causing the accumulation of bacteria at intermediate temperatures. Interestingly, in the presence of Serine only, similar 
behaviour is observed as both the receptors swap their roles [53]. Thus, it suggests that thermotaxis plays an important role in bacterial survival in diverse environments.

\section{Chaperones and Proteases}

The chaperone system in Escherichia coli consists of DnaK (HSP70) which works along its co-chaperone DnaJ and the nucleotide exchange factor GrpE [54]. Primary function of DnaK involves directing substrates for unfolding, disaggregation, refolding or degradation [54]. The long N-terminal $\alpha$-helix of GrpE was observed to function as a thermosensor as under heat stress conditions, paired $\alpha$-helices of GrpE underwent a helix-to-coil transition, which inactivated its nucleotide exchange activity [6]. This in turn inhibited the release of substrate from the chaperone DnaK and resulted in conversion of DnaK from an ATP consuming foldase into a holdase which tightly binds the unfolded polypeptides [6]. In case of Bacillus anthracis, GroEL keeps the protein kinase $\mathrm{C}$ (PrkC) in active conformation during the transition stage such as sporulation and infection. Thus, the GroEL helps in regulating signal transduction proteins involved in bacterial pathogenesis [55]. Even ClpC ATPase, which belongs to the heat shock protein family, have been reported to play an important role in Bacillus anthracis sporulation pathway. ClpC mediated proteolysis of SpoIIAB protein at engulfment stage facilitated spore maturation which is necesarry for this pathogen to survive under harsh conditions inside host cells [56]. Apart from Hsp's, a homolog of cold shock protein, PprM was also found to attribute extreme environment stress tolerance to Deinococcus radiodurans [57].

Apart from this, proteases such as DegS also act as thermosensors, embedded in the inner membrane of the cell. With the help of the periplasmic domain, DegS senses the unfolded, misfolded or degraded outer membrane proteins and thus gets activated thereby cleaving the antisigma factor RseA [58]. This releases the sigma factor $\sigma \mathrm{E}$ leading to the transcription of genes in the $\sigma \mathrm{E}$ regulon.

DegP or HtrA, the most evolved temperature sensing protein in Escherichia coli, was found to have both the chaperone and the protease activity and remarkably switched between both in a temperature-dependent manner $[59,60]$. It has been speculated that at lower temperatures (below $28{ }^{\circ} \mathrm{C}$ ) the proteolytic Ser remains in an inactive conformation resulting in only chaperone activity. However, the increase in temperature could lead to conformational changes thereby promoting protease activity $[60,61]$. Such a mechanism has been also reported in the bacteria Thermotoga maritima, which harbours the chaperone-protease Tm HtrA [6]. It was observed to function as a chaperone at normal temperatures but the elevation in temperature caused the conformational changes thereby switching on its protease activity [6].

\section{Miscellaneous}

\section{Kinases}

Two-component system (TCS) in bacteria comprises a pair of sensor and response regulator proteins which help in responding to a variety of environmental stimuli [62]. The sensor protein is usually membrane-bound Histidine kinase, which upon environmental stimuli auto phosphorylates and transfers the phosphate group to its response regulator protein. The response regulator then activates the transcription of target genes. [51, 62].

In Bacillus subtilis, DesK, which is a Histidine kinase, was found to play an important role in maintaining membrane fluidity at low temperatures [63]. Interestingly, although it lacked the extracytoplasmic signalsensing domain, it sensed the signal via its 10 transmembrane helices. Studies have further proposed that DesK sensed the membrane status such as thickness, fluidity and water permeability and transduced the signal [63]. Apart from this, Dimorphism regulating kinase (Drk1) represents a variant of TCS as it consists of both the sensor and the receiver domain. It is one of the conserved Histidine kinases present in the dimorphic fungi such as Histoplasma capsulatum and Blastomyces dermatitidis. Drk1 has been shown to act as a temperature sensor as it controls morphogenesis as well as adaptation of these fungi to various stresses present inside the mammalian host [2].

There have also been reports depicting the presence of two-component system in plant pathogens like Agrobacterium tumefaciens which control virulence. It consists of the sensor kinase VirA which phosphorylates the response regulator VirG, which in turn activates other sets of vir genes [51]. The vir genes aid in the excision and transfer of T-DNA from the Agrobacterium to the plant host [6]. Various experiments revealed that the expression of virulence occurred only at temperatures below $32{ }^{\circ} \mathrm{C}$ and temperatures above this led to its reversible inactivation of VirA and thus prevented VirG from being phosphorylated [6].

In Synechocystis sp., the membrane fluidity changes under cold temperatures were observed to be controlled by desaturases such as DesB which has been shown to be regulated by Histidine kinases i.e. Hik33 and Hik19 [64, 65]. Hik33 possibly perceived the cold-induced membrane rigidification because of the change in its thickness through the help of its transmembrane domains. The signal is then relayed via Ree 26 response regulator to activate the cold-inducible genes [65]. 


\section{Type VI Secretion System (T6SS)}

The type VI secretion system (T6SS) is responsible for mediating interspecies competition, virulence, and natural transformation in Vibrio cholerae [66]. It has been reported to consist of a base which spans the cell envelope, an inner tube that is composed of hemolysincoregulated protein (Hcp) polymers, and an outer contractile sheath that is formed by VipA and VipB [66]. Further, it was speculated that temperature affected T6SS to a great extent as the message abundance, protein production and secretion, and activity of Hcp were highest at $25^{\circ} \mathrm{C}$ when compared to $37{ }^{\circ} \mathrm{C}$ [66].

\section{Conclusion and Future Prospects}

Heat stress resulting from elevated ambient temperature is one of the most environmental stresses faced by the microbes, particularly when they enter mammalian hosts [67].Thus, the ability to sense and adapt to environmental temperature perturbations represent a life-or-death challenge for several species [68]. Moreover, thermosensors play a vital role in survival and pathogenesis of various microbes as upon host infection the rise in temperature leads to the activation of various virulence factors that help them in immune invasion. Hence, understanding their molecular strategies becomes important as they can be used as potential targets for drug discovery and vaccine development. Thermosensors such as RNA and DNA provide a rapid and specific control upon temperature change whereas protein thermosensors help in bringing about a global change. However, not all thermosensors discovered so far have been elucidated completely. The recent advancements in the field of RNA sequencing can be used to define secondary structures of all transcripts in bacteria and can be compared at different temperatures [44]. Narberhaus and coworkers have successfully used a similar approach on RNA isolated from Yersinia pseudotuberculosis to identify and characterise more than a dozen new thermosensors [69]. Thus, these thermosensing mechanisms will not only aid in elucidating similar strategies in eukaryotes but also help in understanding how temperature orchestrates cellular signaling and development.

Funding HS is thankful to the University Grant Commission (UGC) for the fellowship. This work has been supported by grant from JC Bose fellowship award, Science and Engineering Research Board, Government of India, for research support.

\section{Declarations}

Conflict of interest The authors declare that the research was conducted in absence of any commercial or financial relationship that could be construed as a potential conflict of interest.

\section{References}

1. García-Ávila M, Islas LD (2019) What is new about mild temperature sensing? a review of recent findings. Temp Multidiscip Biomed J 6:132-141. https://doi.org/10.1080/23328940.2019. 1607490

2. Shapiro RS, Cowen LE (2012) Thermal control of microbial development and virulence: molecular mechanisms of microbial temperature sensing. MBio. https://doi.org/10.1128/mBio.0023812

3. Fang FC, Frawley ER, Tapscott T, Vázquez-Torres A (2016) Bacterial stress responses during host infection. Cell Host Microbe 20:133-143. https://doi.org/10.1016/j.chom.2016.07.009

4. Zhang Y, Gross CA (2021) Cold shock response in bacteria. Annu Rev Genet. https://doi.org/10.1146/annurev-genet-071819031654

5. Schumann W (2016) Regulation of bacterial heat shock stimulons. Cell Stress Chaperones 21:959-968. https://doi.org/10.1007/ s12192-016-0727-z

6. Klinkert B, Narberhaus F (2009) Microbial thermosensors. Cell Mol Life Sci 66:2661-2676. https://doi.org/10.1007/s00018-0090041-3

7. Hayes S, Schachtschabel J, Mishkind M et al (2021) Hot topic: thermosensing in plants. Plant Cell Environ 44:2018-2033. https://doi.org/10.1111/pce.13979

8. de Mendoza D, Pilon M (2019) Control of membrane lipid homeostasis by lipid-bilayer associated sensors: a mechanism conserved from bacteria to humans. Prog Lipid Res 76:100996. https://doi.org/10.1016/j.plipres.2019.100996

9. Mironov KS, Sidorov RA, Trofimova MS et al (2012) Lightdependent cold-induced fatty acid unsaturation, changes in membrane fluidity, and alterations in gene expression in Synechocystis. Biochim Biophys Acta 1817:1352-1359. https://doi. org/10.1016/j.bbabio.2011.12.011

10. Mironov KS, Shumskaya M, Sidorov RA et al (2018) Membrane physical state and stress regulation in Synechocystis: fluidizing alcohols repress fatty acid desaturation. Plant J 96:1007-1017. https://doi.org/10.1111/tpj.14086

11. Aguilar PS, Hernandez-Arriaga AM, Cybulski LE et al (2001) Molecular basis of thermosensing: a two-component signal transduction thermometer in Bacillus subtilis. EMBO J 20:1681-1691. https://doi.org/10.1093/emboj/20.7.1681

12. Shen L, Zhang S, Chen G (2021) Regulated strategies of coldadapted microorganisms in response to cold: a review. Environ Sci Pollut Res. https://doi.org/10.1007/s11356-021-16843-6

13. Chandler CE, Ernst RK (2017) Bacterial lipids powerful modifiers of the innate immune response. F1000Res 45:456

14. Phillips NJ, Schilling B, McLendon MK et al (2004) Novel modification of lipid A of Francisella tularensis. Infect Immun 72:5340-5348. https://doi.org/10.1128/IAI.72.9.5340-5348.2004

15. Li Y, Powell DA, Shaffer SA et al (2012) LPS remodeling is an evolved survival strategy for bacteria. Proc Natl Acad Sci USA 109:8716-8721. https://doi.org/10.1073/pnas.1202908109

16. Jones CL, Napier BA, Sampson TR et al (2012) Subversion of host recognition and defense systems by Francisella spp. 
Microbiol Mol Biol Rev 76:383-404. https://doi.org/10.1128/ MMBR.05027-11

17. Steimle A, Autenrieth IB, Frick J-S (2016) Structure and function: lipid a modifications in commensals and pathogens. Int $\mathrm{J}$ Med Microbiol 306:290-301. https://doi.org/10.1016/j.ijmm. 2016.03.001

18. Schumann W (2017) Regulation of the heat shock response in bacteria. In: Kumar CMS, Mande SC (eds) Prokaryotic chaperonins. Springer Singapore, Singapore, pp 21-36

19. Dawoud TM, Davis ML, Park SH et al (2017) The potential link between thermal resistance and virulence in Salmonella: a review. Front Vet Sci 4:93. https://doi.org/10.3389/fvets.2017. 00093

20. Katayama S, Matsushita O, Jung CM et al (1999) Promoter upstream bent DNA activates the transcription of the Clostridium perfringens phospholipase $\mathrm{C}$ gene in a low temperature-dependent manner. EMBO J 18:3442-3450. https://doi.org/10.1093/ emboj/18.12.3442

21. Roncarati D, Scarlato V (2017) Regulation of heat-shock genes in bacteria: from signal sensing to gene expression output. FEMS Microbiol Rev 41:549-574. https://doi.org/10.1093/femsre/ fux015

22. Ono S, Goldberg MD, Olsson T et al (2005) H-NS is a part of a thermally controlled mechanism for bacterial gene regulation. Biochem J 391:203-213. https://doi.org/10.1042/BJ20050453

23. Duong N, Osborne S, Bustamante VH et al (2007) Thermosensing coordinates a cis-regulatory module for transcriptional activation of the intracellular virulence system in Salmonella enterica serovar Typhimurium. J Biol Chem 282:34077-34084. https://doi.org/10.1074/jbc.M707352200

24. Falconi M, Colonna B, Prosseda G et al (1998) Thermoregulation of Shigella and Escherichia coli EIEC pathogenicity. A temperature-dependent structural transition of DNA modulates accessibility of virF promoter to transcriptional repressor H-NS. EMBO J 17:7033-7043. https://doi.org/10.1093/emboj/17.23.7033

25. Madrid C, Nieto JM, Paytubi S et al (2002) Temperature- and H-NS-dependent regulation of a plasmid-encoded virulence operon expressing Escherichia coli hemolysin. J Bacteriol 184:5058-5066. https://doi.org/10.1128/JB.184.18.5058-5066. 2002

26. Abduljalil JM (2018) Bacterial riboswitches and RNA thermometers: nature and contributions to pathogenesis. Non-Coding RNA Res 3:54-63. https://doi.org/10.1016/j.ncrna.2018.04.003

27. Narberhaus F, Käser R, Nocker A, Hennecke H (1998) A novel DNA element that controls bacterial heat shock gene expression. Mol Microbiol 28:315-323. https://doi.org/10.1046/j.1365-2958. 1998.00794.x

28. Kortmann J, Narberhaus F (2012) Bacterial RNA thermometers: molecular zippers and switches. Nat Rev Microbiol 10:255-265. https://doi.org/10.1038/nrmicro2730

29. Grosso-Becerra MV, Croda-García G, Merino E et al (2014) Regulation of Pseudomonas aeruginosa virulence factors by two novel RNA thermometers. Proc Natl Acad Sci USA 111:15562-15567. https://doi.org/10.1073/pnas.1402536111

30. Waldminghaus T, Heidrich N, Brantl S, Narberhaus F (2007) FourU: a novel type of RNA thermometer in Salmonella. Mol Microbiol 65:413-424. https://doi.org/10.1111/j.1365-2958.2007. 05794.x

31. Grosso-Becera MV, Servín-González L, Soberón-Chávez G (2015) RNA structures are involved in the thermoregulation of bacterial virulence-associated traits. Trends Microbiol 23:509-518. https://doi.org/10.1016/j.tim.2015.04.004

32. Wagner D, Rinnenthal J, Narberhaus F, Schwalbe H (2015) Mechanistic insights into temperature-dependent regulation of the simple cyanobacterial hsp17 RNA thermometer at base-pair resolution. Nucleic Acids Res 43:5572-5585. https://doi.org/10. 1093/nar/gkv414

33. Barros SA, Yoon I, Chenoweth DM (2016) Modulation of the E. coli rpoH temperature sensor with triptycene-based small molecules. Angew Chem Int Ed 55:8258-8261. https://doi.org/ 10.1002/anie. 201601626

34. Lybecker MC, Samuels DS (2007) Temperature-induced regulation of RpoS by a small RNA in Borrelia burgdorferi. Mol Microbiol 64:1075-1089. https://doi.org/10.1111/j.1365-2958. 2007.05716.x

35. Klein G, Raina S (2017) Small regulatory bacterial RNAs regulating the envelope stress response. Biochem Soc Trans 45:417-425. https://doi.org/10.1042/BST20160367

36. Rennella E, Sára T, Juen M et al (2017) RNA binding and chaperone activity of the E. coli cold-shock protein CspA. Nucleic Acids Res. https://doi.org/10.1093/nar/gkx044

37. Twittenhoff C, Heroven AK, Mühlen S et al (2020) An RNA thermometer dictates production of a secreted bacterial toxin. PLOS Pathog 16:e1008184. https://doi.org/10.1371/journal.ppat. 1008184

38. Barnwal RP, Loh E, Godin KS et al (2016) Structure and mechanism of a molecular rheostat, an RNA thermometer that modulates immune evasion by Neisseria meningitidis. Nucleic Acids Res. https://doi.org/10.1093/nar/gkw584

39. Zhang H, Hall I, Nissley AJ et al (2020) A tale of two transitions: The unfolding mechanism of the prfA RNA thermosensor. Biochemistry 59:4533-4545. https://doi.org/10.1021/acs.biochem. $0 \mathrm{c} 00588$

40. Brewer SM, Twittenhoff C, Kortmann J et al (2021) A Salmonella Typhi RNA thermosensor regulates virulence factors and innate immune evasion in response to host temperature. PLOS Pathog 17:e1009345. https://doi.org/10.1371/journal.ppat. 1009345

41. Eichner H, Karlsson J, Spelmink L et al (2021) RNA thermosensors facilitate Streptococcus pneumoniae and Haemophilus influenzae immune evasion. PLOS Pathog 17:e1009513. https:// doi.org/10.1371/journal.ppat.1009513

42. Hussein H, Fris ME, Salem AH et al (2019) An unconventional RNA-based thermosensor within the 5' UTR of Staphylococcus aureus cidA. PLoS ONE 14:e0214521. https://doi.org/10.1371/ journal.pone. 0214521

43. Loh E, Righetti F, Eichner H et al (2018) RNA thermometers in bacterial pathogens. Microbiol Spectr. https://doi.org/10.1128/ microbiolspec.RWR-0012-2017

44. Mandin P, Johansson J (2020) Feeling the heat at the millennium: Thermosensors playing with fire. Mol Microbiol 113:588-592. https://doi.org/10.1111/mmi.14468

45. Nuss AM, Schuster F, Roselius L et al (2016) A precise temperature-responsive bistable switch controlling Yersinia virulence. PLoS Pathog 12:e1006091. https://doi.org/10.1371/journal. ppat. 1006091

46. Rossi CC, de Oliveira LL, de Carvalho RD et al (2017) Expression of the stress-response regulators CtsR and HrcA in the uropathogen Staphylococcus saprophyticus during heat shock. Antonie Van Leeuwenhoek 110:1105-1111. https://doi.org/10. 1007/s10482-017-0881-z

47. Elsholz AKW, Michalik S, Zühlke D et al (2010) CtsR, the Gram-positive master regulator of protein quality control, feels the heat. EMBO J 29:3621-3629. https://doi.org/10.1038/emboj. 2010.228

48. Darsonval M, Julliat F, Msadek T et al (2018) CtsR, the master regulator of stress-response in Oenococcus oeni, is a heat sensor interacting with ClpL1. Front Microbiol 9:3135. https://doi.org/ 10.3389/fmicb.2018.03135

49. Hanson BR, Tan M (2015) Transcriptional regulation of the Chlamydia heat shock stress response in an intracellular 
infection: In vivo analysis of Chlamydia stress response. Mol Microbiol 97:1158-1167. https://doi.org/10.1111/mmi.13093

50. Versace G, Palombo M, Menon A et al (2021) Feeling the heat: the Campylobacter jejuni HrcA transcriptional repressor is an intrinsic protein thermosensor. Biomolecules 11:1413. https://doi. org/10.3390/biom11101413

51. Sengupta P, Garrity P (2013) Sensing temperature. Curr Biol CB 23:R304-R307. https://doi.org/10.1016/j.cub.2013.03.009

52. Salah Ud-Din AIM, Roujeinikova A (2017) Methyl-accepting chemotaxis proteins: a core sensing element in prokaryotes and archaea. Cell Mol Life Sci CMLS 74:3293-3303. https://doi.org/ 10.1007/s00018-017-2514-0

53. Paulick A, Jakovljevic V, Zhang S et al (2017) Mechanism of bidirectional thermotaxis in Escherichia coli. Elife 6:e26607. https://doi.org/10.7554/eLife.26607

54. Saibil H (2013) Chaperone machines for protein folding, unfolding and disaggregation. Nat Rev Mol Cell Biol 14:630-642. https://doi.org/10.1038/nrm3658

55. Virmani R, Singh Y, Hasija Y (2018) GroEL mediates folding of Bacillus anthracis Serine/Threonine protein kinase, PrkC. Indian J Microbiol 58:520-524. https://doi.org/10.1007/s12088-0180744-y

56. Kumar N, Gangwal A, Sangwan N et al (2021) ClpC-mediated sporulation regulation at engulfment stage in Bacillus anthracis. Indian J Microbiol 61:170-179. https://doi.org/10.1007/s12088021-00927-5

57. Li W, Ma Y, Yang J et al (2017) RNA-binding domain is necessary for PprM function in response to the extreme environmental stress in Deinococcus radiodurans. Indian J Microbiol 57:492-498. https://doi.org/10.1007/s12088-017-0684-y

58. Konovalova A, Grabowicz M, Balibar CJ et al (2018) Inhibitor of intramembrane protease RseP blocks the $\sigma^{\mathrm{E}}$ response causing lethal accumulation of unfolded outer membrane proteins. Proc Natl Acad Sci USA 115:E6614-E6621. https://doi.org/10.1073/ pnas. 1806107115

59. Spiess C, Beil A, Ehrmann M (1999) A temperature-dependent switch from chaperone to protease in a widely conserved heat shock protein. Cell 97:339-347. https://doi.org/10.1016/s00928674(00)80743-6

60. Kim H, Wu K, Lee C (2021) Stress-responsive periplasmic chaperones in bacteria. Front Mol Biosci 8:357. https://doi.org/ 10.3389/fmolb.2021.678697
61. Ortega J, Iwanczyk J, Jomaa A (2009) Escherichia coli DegP: a structure-driven functional model. J Bacteriol 191:4705-4713. https://doi.org/10.1128/JB.00472-09

62. Liu C, Sun D, Zhu J, Liu W (2019) Two-component signal transduction systems: a major strategy for connecting input stimuli to biofilm formation. Front Microbiol 9:3279. https://doi. org/10.3389/fmicb.2018.03279

63. Abriata LA, Albanesi D, Dal Peraro M, de Mendoza D (2017) Signal sensing and transduction by Histidine kinases as unveiled through studies on a temperature sensor. Acc Chem Res 50:1359-1366. https://doi.org/10.1021/acs.accounts.6b00593

64. Suzuki I (2000) The pathway for perception and transduction of low-temperature signals in Synechocystis. EMBO J 19:1327-1334. https://doi.org/10.1093/emboj/19.6.1327

65. Xu W, Wang Y (2019) Sequences, domain architectures, and biological functions of the Serine/Threonine and Histidine kinases in Synechocystis sp. PCC 6803. Appl Biochem Biotechnol 188:1022-1065. https://doi.org/10.1007/s12010-019-02971-w

66. Townsley L, Sison Mangus MP, Mehic S, Yildiz FH (2016) Response of Vibrio cholerae to Low-temperature shifts: CspV regulation of type VI secretion, biofilm formation, and association with zooplankton. Appl Environ Microbiol 82:4441-4452. https://doi.org/10.1128/AEM.00807-16

67. Qu Q, Li H, Bai L et al (2021) Effects of heat stress on gut microbiome in rats. Indian J Microbiol 61:338-347. https://doi. org/10.1007/s12088-021-00948-0

68. Sunilkumar C-R, Stephen-Victor E, Naripogu KB et al (2021) Differential multi-cellularity is required for the adaptation for Bacillus licheniformis to withstand heavy metals toxicity. Indian J Microbiol 61:524-529. https://doi.org/10.1007/s12088-02100958-y

69. Righetti F, Nuss AM, Twittenhoff $\mathrm{C}$ et al (2016) Temperatureresponsive in vitro RNA structurome of Yersinia pseudotuberculosis. Proc Natl Acad Sci USA 113:7237-7242. https://doi.org/ 10.1073/pnas. 1523004113

Publisher's Note Springer Nature remains neutral with regard to jurisdictional claims in published maps and institutional affiliations. 